\title{
Prevalence of enamel white spots and risk factors in children up to 36 months old
}

\section{Ana Valéria Pagliari Tiano(a) Suzely Adas Saliba Moimaz ${ }^{(b)}$ Orlando Saliba ${ }^{(c)}$ \\ Cléa Adas Saliba Garbin ${ }^{(b)}$}

(a) MSc, PhD Candidate in Preventive and Social Dentistry; ${ }^{(b)}$ PhD, Associate Professor; (c) PhD, Professor, Preventive and Social Dentistry Graduate Program - School of Dentistry of Araçatuba, São Paulo State University (UNESP), Araçatuba, SP, Brazil.

\begin{abstract}
The aim of this study was to determine the prevalence of enamel white spots and the quality of oral hygiene in children up to 36 months old, in municipalities with different fluoride levels in the water supply, analyzing the contribution of several variables. After approval of the Ethics Committee, the parents signed an informed consent form and were interviewed about their educational level, economic classification of the family, nursing habits, use of toothpaste, access to dental service and other information. The children were clinically examined using the same codes and criteria established by the WHO (World Health Organization) and ADA (American Dental Association). The data were processed and analyzed with the Epi-info software program, version 3.2, and Microsoft Excel. Fisher's exact test $(\mathrm{p}<0.05)$ was applied to assess the association among the variables. The enamel white spot prevalence was $30.8 \%$ and the age group, duration of the bedtime milk feeding habit, age of initial practice of oral hygiene and presence of caries lesions with cavitation were considered statistically significant with regard to enamel white spot prevalence $(\mathrm{p}<0.05)$. No association was found between oral hygiene quality and the study variables.
\end{abstract}

Descriptors: Oral health; Dental caries; Oral hygiene.

\section{Corresponding author:}

Ana Valéria Pagliari Tiano

Av. José Maria de Brito, 745, Ap. 103

Foz do Iguaçu - PR - Brazil

CEP: 85864-320

E-mail: anapagliari@yahoo.com.br 


\section{Introduction}

Dental caries is defined as an infectious disease that consists of the demineralization of dental tissues exposed to acidogenic microorganisms and fermentable carbohydrates, being influenced by several factors. ${ }^{1-3}$

At an initial stage, the mineral loss produces microporosities that can be recognized clinically by the formation of white, opaque and rough areas. These white spot lesions inevitably develop into lesions with cavitation, if the mineral loss continues. ${ }^{1,4}$

The expression "early childhood caries" has been used to refer to any stage of caries lesion, on any deciduous tooth surface of children up to 71 months of age. ${ }^{1}$ Because it is considered a public health problem, ${ }^{1,5,6}$ the need to know the actual prevalence of the disease is justified, including information about all its stages, in the different population groups, as well as the risk factors connected with its occurrence. ${ }^{7}$

The aim of this study was to determine the prevalence of tooth enamel white spots and the quality of oral hygiene in children up to 36 months old, registered in public daycare centers of two municipalities with different fluoride concentrations in the water supply, evaluating the contribution of biological, socio-economic and behavioral variables to the occurrence of this incipient lesion.

\section{Material and Methods}

The study was conducted during 2006 in two municipalities in the State of São Paulo, Brazil. In the municipality of Clementina (Low Fluoride Content - LFC) fluoride is not added to the water supply and the natural content is lower than $0.40 \mathrm{mg} \mathrm{F} / \mathrm{L} .{ }^{2}$ During the study period, the only municipal daycare center had 47 children registered, ranging from 6 to 35 months of age. The municipality of Gabriel Monteiro (Adequate Fluoride Content - AFC) has fluoride added to its water supply. Fluoride content is constant and considered optimum, ranging from 0.60 to $0.75 \mathrm{mg} \mathrm{F} / \mathrm{L} .{ }^{2}$ In the study period, the only municipal daycare center had 41 children registered, ranging from 6 to 36 months of age.

Neither of the centers provides any kind of educational or preventive program with regard to oral health and the caregivers showed no awareness about the need for cleaning the teeth of children up to 36 months old, who take baby bottles sweetened with sugar daily.

After approval of the Human Research Ethics Committee, São Paulo State University (UNESP), the parents or caregivers signed an informed consent form allowing the children to take part in the study. Next, they were interviewed with the aid of a structured questionnaire, which included questions about the family's economic classification, ${ }^{8}$ the parents' ages and educational level, whether the children had any brothers or sisters, their nursing habits, consumption of water from the public water supply, use of toothpaste, access to dental service and guidance about oral health care.

The exclusion criteria were: absence of parental consent to examine the child or absence of teeth.

The clinical examinations were carried out at the daycare centers, under natural light, by a single examiner, trained and calibrated (kappa 0.91 for lesions with cavitation; 0.90 for lesions without cavitation and 0.97 for hygiene index), who assumed a knee-to-knee position and was helped by an assistant and a note taker.

Oral hygiene quality was assessed using the Greene and Vermillion index ${ }^{9}$ (1960). It was decided that all fully erupted teeth would be included, because of the ages of the children examined and the chronology of tooth eruption. A plaque-disclosing solution was applied to the buccal and lingual surfaces.

Two days later the conditions of the dental crowns were assessed with the use of an oral mirror and a WHO (World Health Organization) probe. Before examination, the children's teeth were cleaned and dried with gauze. The same codes and criteria established by the $\mathrm{WHO}^{10}$ (1997) and used in the national survey ${ }^{11}$ were applied. White spot lesion identification was conducted separately, according to the criteria proposed by the ADA (American Dental Association). ${ }^{1}$

The data were processed and analyzed with the Epi-info software program, version 3.2. The means and standard deviations (mean $\pm \mathrm{SD}$ ) of the examined children's ages, and the means, standard deviations and 95\% confidence interval (mean \pm SD; 95\% CI) of the dmft and dmfs were calculated. Fisher's 
exact test, with significance level at 5\%, was applied to assess the association between the variables studied, using the BiosEstat 4.0 software program.

\section{Results}

In the two daycare centers, 68 children were examined. In the LFC municipality 38 children ranging between the ages of 8 and 36 months $(23.70 \pm 8.30)$ participated in the study. In the AFC municipality there were 30 children ranging between the ages of 8 and 36 months $(23.63 \pm 9.28)$.

The $\mathrm{dmft}$ and $\mathrm{dmfs}$ indices were higher in the LFC municipality. These data are presented in Table 1.

The prevalences of white spot lesions and caries lesions with cavitation are shown in Graph 1.

The association between white spot lesions and the variables studied is presented in Table 2. Re-

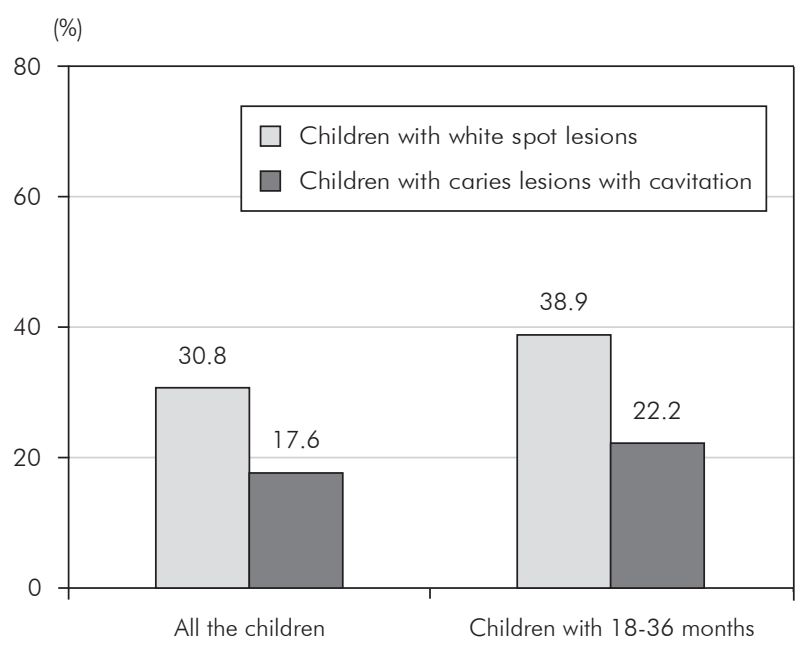

Graph 1 - Prevalence of white spot lesions and caries lesions with cavitation in the children examined. garding the fluoride contents in the two communities, Fisher's exact test revealed no statistically significant differences between them $(\mathrm{p}=0.601)$.

Fisher's exact test revealed no statistically significant differences among children's oral hygiene quality and the same study variables tested for white spot lesions shown in Table 2.

As regards the oral hygiene practices, $82.3 \%$ of the parents related that they clean their children's mouths, and $71.4 \%$ of them do so daily. Table 3 presents the oral hygiene quality of the children examined.

\section{Discussion}

The first official data about the oral health status of Brazilian children younger than 3 years old were collected in the national survey carried out in $2002-2003 .{ }^{11}$ The survey revealed that $26.8 \%$ of the children from 18 to 36 months old had already experienced dental caries. Among the residents of the southeastern region, the prevalence was $23.2 \%$ in the same age group. The caries prevalence observed in this study was similar to the national and the southeastern region prevalence (Graph 1).

However, the national survey did not include data about caries lesions without cavitation. ${ }^{11}$ When these lesions are considered in the clinical exam, the caries prevalence in children up to 36 months of age can reach $55 \% .^{12}$ In the present study the presence of white spots was strongly associated $(\mathrm{p}<0.001)$ with the presence of caries lesions with cavitation (Table 2), proving the relevance of including white spot lesions in the clinical exam of this age group. ${ }^{7}$

As reported by other authors, ${ }^{7,12-17}$ dental caries

Table 1 - Mean, standard deviation and $95 \%$ confidence interval of the $\mathrm{dmft}$ and $\mathrm{dmfs}$ indices of the children examined in each municipality.

\begin{tabular}{l|c|c|c}
\hline \multirow{2}{*}{ Municipality } & \multirow{2}{*}{ Age (months) } & \multicolumn{2}{|c}{ Mean \pm SD $(95 \% \mathrm{Cl})$} \\
\cline { 2 - 4 } & & $\mathrm{dmf-}+$ & $\mathrm{dmf}-\mathrm{s}$ \\
\hline \multirow{2}{*}{ LFC } & 18 to 36 & $0.84 \pm 2.00(0.36-1.31)$ & $1.39 \pm 4.70(0.27-2.50)$ \\
\cline { 2 - 4 } & Up to 36 & $0.68 \pm 1.83(0.10-1.27)$ & $1.13 \pm 4.26(0.00-2.49)$ \\
\hline \multirow{2}{*}{ AFC } & 18 to 36 & $0.74 \pm 2.16(0.23-1.25)$ & $1.30 \pm 4.04(0.34-2.26)$ \\
\cline { 2 - 4 } & Up to 36 & $0.57 \pm 1.91(0.00-1.25)$ & $1.00 \pm 3.56(0.00-2.27)$ \\
\hline \multirow{2}{*}{ Total } & 18 to 36 & $0.80 \pm 2.05(0.31-1.28)$ & $1.35 \pm 4.39(0.31-2.39)$ \\
\cline { 2 - 4 } & Up to 36 & $0.63 \pm 1.85(0.19-1.07)$ & $1.07 \pm 3.94(0.14-2.01)$ \\
\hline
\end{tabular}

LFC: low fluoride content; AFC: adequate fluoride content. 
Table 2 - Prevalence of white spots in the 68 children examined, according to the variables studied.

\begin{tabular}{|c|c|c|c|c|c|c|c|c|}
\hline \multirow{2}{*}{\multicolumn{2}{|c|}{ Variables }} & \multicolumn{2}{|c|}{ With white spots } & \multicolumn{2}{|c|}{ Without white spots } & \multicolumn{2}{|c|}{ Total } & \multirow{2}{*}{$P$} \\
\hline & & $\mathrm{n}$ & $\%$ & $\mathrm{n}$ & $\%$ & $\mathrm{n}$ & $\%$ & \\
\hline \multirow{2}{*}{ Age group (months) } & Up to 17 & 0 & 0.0 & 14 & 100 & 14 & 100.0 & \multirow{2}{*}{$0.003^{*}$} \\
\hline & 18 to 36 & 21 & 38.9 & 33 & 61.1 & 54 & 100.0 & \\
\hline \multirow{2}{*}{ Economic classification ${ }^{\dagger}$} & $B$ and $C$ & 12 & 27.9 & 31 & 72.1 & 43 & 100.0 & \multirow{2}{*}{0.588} \\
\hline & $\mathrm{D}$ and $\mathrm{E}$ & 9 & 36.0 & 16 & 64.0 & 25 & 100.0 & \\
\hline \multirow{2}{*}{$\begin{array}{l}\text { Father's educational level } \\
\text { (years of schooling) }\end{array}$} & Up to 8 & 14 & 32.6 & 29 & 67.4 & 43 & 100.0 & \multirow{2}{*}{0.789} \\
\hline & 9 or more & 7 & 28.0 & 18 & 72.0 & 25 & 100.0 & \\
\hline \multirow{2}{*}{$\begin{array}{l}\text { Mother's educational level } \\
\text { (years of schooling) }\end{array}$} & Up to 8 & 11 & 32.4 & 23 & 67.6 & 34 & 100.0 & \multirow{2}{*}{0.800} \\
\hline & 9 or more & 10 & 29.4 & 24 & 70.6 & 34 & 100.0 & \\
\hline \multirow{2}{*}{ Father's age (years) } & Up to 25 & 7 & 23.3 & 23 & 76.6 & 30 & 100.0 & \multirow{2}{*}{0.294} \\
\hline & 26 or more & 14 & 36.8 & 24 & 63.2 & 38 & 100.0 & \\
\hline \multirow{2}{*}{ Mother's age (years) } & Up to 25 & 12 & 33.3 & 24 & 66.7 & 36 & 100.0 & \multirow{2}{*}{0.793} \\
\hline & 26 or more & 9 & 28.1 & 23 & 71.9 & 32 & 100.0 & \\
\hline \multirow{2}{*}{ Existence of brothers or sisters } & Yes & 7 & 33.3 & 14 & 66.7 & 21 & 100.0 & \multirow{2}{*}{0.783} \\
\hline & No & 14 & 29.8 & 33 & 70.2 & 47 & 100.0 & \\
\hline \multirow{2}{*}{$\begin{array}{l}\text { Duration of breast feeding } \\
\text { (months) }\end{array}$} & Up to 12 & 15 & 31.9 & 32 & 68.1 & 47 & 100.0 & \multirow{2}{*}{0.527} \\
\hline & 13 or more & 6 & 42.9 & 8 & 57.1 & 14 & 100.0 & \\
\hline \multirow{2}{*}{$\begin{array}{l}\text { Duration of bedtime feeding } \\
\text { (months) }\end{array}$} & Up to 12 & 0 & 0.0 & 14 & 100 & 14 & 100.0 & \multirow{2}{*}{$0.003^{*}$} \\
\hline & 13 or more & 21 & 38.9 & 33 & 61.1 & 54 & 100.0 & \\
\hline \multirow{2}{*}{$\begin{array}{l}\text { Duration of nighttime feeding } \\
\text { (months) }\end{array}$} & Up to 12 & 7 & 25.9 & 20 & 74.1 & 27 & 100.0 & 702 \\
\hline & 13 or more & 10 & 29.4 & 24 & 70.6 & 34 & 100.0 & 0.103 \\
\hline 管 & Yes & 18 & 32.1 & 38 & 67.9 & 56 & 100.0 & 710 \\
\hline 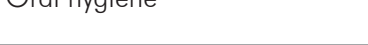 & No & 3 & 25.0 & 9 & 75.0 & 12 & 100.0 & 0.142 \\
\hline Frequency of oral hygiene & None / occasionally & 8 & 28.6 & 20 & 71.4 & 28 & 100.0 & 704 \\
\hline (times a day) & At least 1 & 13 & 32.5 & 27 & 67.5 & 40 & 100.0 & 0.194 \\
\hline Age of initial practice of oral & Up to 11 & 3 & 13.0 & 20 & 87.0 & 23 & 100.0 & * 00 \\
\hline hygiene (months) & 12 or more & 15 & 45.5 & 18 & 54.5 & 33 & 100.0 & $0.019^{\circ}$ \\
\hline 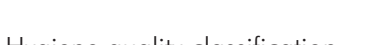 & Good or fair & 14 & 35.0 & 26 & 65.0 & 40 & 100.0 & 0120 \\
\hline nygiene quanty ciassification & Poor & 7 & 25.0 & 21 & 75.0 & 28 & 100.0 & 0.433 \\
\hline 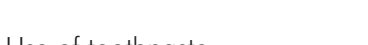 & Yes & 17 & 35.4 & 31 & 64.6 & 48 & 100.0 & 0250 \\
\hline Use of tootnpaste & No & 4 & 20.0 & 16 & 80.0 & 20 & 100.0 & 0.259 \\
\hline Age of initial use of toothpaste & Up to 11 & 1 & 14.3 & 6 & 85.7 & 7 & 100.0 & 206 \\
\hline (months) & 12 or more & 16 & 39.0 & 25 & 61.0 & 41 & 100.0 & 0.390 \\
\hline Fluoride content & AFC & 8 & 26.7 & 22 & 73.3 & 30 & 100.0 & 0601 \\
\hline in water & LFC & 13 & 34.2 & 25 & 65.8 & 38 & 100.0 & 0.601 \\
\hline Caries lesions with cavity & Yes & 11 & 91.6 & 1 & 8.4 & 12 & 100.0 & $<0 \cap 01 *$ \\
\hline Caries lesions Wirn cavity & No & 10 & 17.9 & 46 & 82.1 & 56 & 100.0 & $<0.001$ \\
\hline A & Yes & 4 & 50.0 & 4 & 50.0 & 8 & 100.0 & 0 \\
\hline Access to dental service & No & 17 & 28.3 & 43 & 71.7 & 60 & 100.0 & 0.240 \\
\hline Guidance about oral & Yes & 5 & 26.3 & 14 & 73.7 & 19 & 100.0 & 0772 \\
\hline health care & No & 16 & 32.7 & 33 & 67.3 & 49 & 100.0 & 0.112 \\
\hline
\end{tabular}

teconomic classification: ABEP8 (2003). Average monthly family income: U\$213 to U\$1,402 - classes B and C; U\$103 to U\$212 - classes D and E. ${ }^{*}(p<0.05)$ - Fisher's exact test. 
Table 3 - Hygiene score in relation to tooth surface and classification of the children according to oral hygiene quality in the two communities.

\begin{tabular}{|c|c|c|c|c|c|c|}
\hline \multirow{3}{*}{$\begin{array}{l}\text { Oral hygiene } \\
\text { Score by surface }\end{array}$} & \multicolumn{4}{|c|}{ Municipality } & \multirow{2}{*}{\multicolumn{2}{|c|}{ Total }} \\
\hline & \multicolumn{2}{|c|}{ LFC } & \multicolumn{2}{|c|}{ AFC } & & \\
\hline & $\mathrm{n}$ & $\%$ & $\mathrm{n}$ & $\%$ & $n$ & $\%$ \\
\hline 0 & 51 & 4.1 & 84 & 9.2 & 135 & 6.3 \\
\hline 1 & 410 & 33.2 & 326 & 35.7 & 736 & 34.3 \\
\hline 2 & 495 & 40.0 & 410 & 45.0 & 905 & 42.1 \\
\hline 3 & 280 & 22.7 & 92 & 10.1 & 372 & 17.3 \\
\hline Total & 1,236 & 100.0 & 912 & 100.0 & 2,148 & 100.0 \\
\hline $\begin{array}{c}\text { Hygiene quality } \\
\text { classification by children }\end{array}$ & $\mathrm{n}$ & $\%$ & $n$ & $\%$ & $n$ & $\%$ \\
\hline Good & 1 & 2.6 & 0 & 0.0 & 1 & 1.5 \\
\hline Fair & 18 & 47.4 & 21 & 70.0 & 39 & 57.3 \\
\hline Poor & 19 & 50.0 & 9 & 30.0 & 28 & 41.2 \\
\hline Total & 38 & 100.0 & 30 & 100.0 & 68 & 100.0 \\
\hline
\end{tabular}

had an early onset in this young population. The prevalence of white spots increased with age ( $\mathrm{Ta}-$ ble 2) and presented statistically significant difference $(p=0.003)$ with regard to age group.

The relationship between caries and milk feeding is controversial in literature. While some authors consider nighttime breastfeeding or bottle-feeding a factor linked to early caries, ${ }^{18,19}$ other researchers did not observe this association..$^{5,12,17,20}$ In the present study, the children beyond 12 months of age who were breastfed at any time, breast- or bottle-fed during the night, or before going to sleep presented a higher prevalence of white spot lesions. Only the last variable (breast- or bottle-fed before going to sleep) was considered statistically significant $(\mathrm{p}=0.003)$.

Children from economic classes D and E, from parents with a lower educational level, from younger mothers and from families with more than one child, presented a higher white spot prevalence; however, neither of those variables were considered statistically significant.

According to the parents, in the municipality with AFC in the water supply, only $54.5 \%$ of the children consume this water. At the daycare center in that municipality, only mineral water without fluoride is consumed. Perhaps this is the reason why water fluoridation, which has a proven action of reducing dental caries, ${ }^{21}$ did not present a statistically significant difference in this study.
The use of fluoridated toothpaste was also not related to a lower white spot prevalence. This can be explained by the length of time the children stay at the daycare center, the whole day, five times a week, bearing in mind that during that time their teeth are not brushed. In fact, as mentioned above, neither of the centers provides any kind of preventive care to the children. Furthermore, $72.1 \%$ of the parents affirmed that they had never received guidance with regard to the oral health of their children. Even so, the early use of fluoridated toothpaste seems to have contributed to reducing the prevalence (Table 2).

The presence of visible biofilm has been associated with caries prevalence. ${ }^{12,18,20}$ However, in this study no relationship between the quality of oral hygiene and the prevalence of white spots or caries lesions with cavitation was observed, as in some other studies. ${ }^{13,16}$

This result can be explained by the methodological differences in the classification of hygiene and because the population examined in this study presented a large amount of bacterial plaque (Table 3).

Santos et al. ${ }^{22}$ (2007) observed that, for young children, a more frequent habit of toothbrushing may not reflect a better oral hygiene quality. Of the total number of children examined in the present study, only $1(1.5 \%)$ had good oral hygiene (Table 3$)$. Nevertheless, most of the parents related that they clean their children's mouths daily, and those who started 
oral hygiene before 12 months of age presented a lower prevalence of white spots $(\mathrm{p}=0.019)$.

Access to dental care presented no relationship with white spot prevalence or oral hygiene quality, since $88.2 \%$ of the children examined had never been to the dentist.

Research conducted in Brazil has detected caries lesions with cavitation in more than $40 \%$ of the 48-month-old children examined. ${ }^{6,23}$ If the children who participated in this study are not offered proper treatment they may reach that level within a short period of time.

The need to instruct the parents about their children's oral health care and adequate use of fluoridated toothpaste became evident, as well as the need to instruct and train the caregivers with regard to the children's oral hygiene during their stay at the daycare centers. ${ }^{20}$ Thus, after data collection had been completed, the parents and daycare center employees and caregivers participated in guidance meetings

\section{References}

1. Drury TF, Horowitz AM, Ismail AI, Maertens MP, Rozier RG, Selwitz RH. Diagnosing and reporting early childhood caries for research purposes. A report of a workshop sponsored by the National Institute of Dental and Craniofacial Research, the Health Resources and Services Administration, and the Health Care Financing Administration. J Public Health Dent. 1999 Summer;59(3):192-7.

2. Saliba NA, Moimaz SA, Tiano AV. Fluoride level in public water supplies of cities from the northwest region of São Paulo state, Brazil. J Appl Oral Sci. 2006 Sep-Oct;14(5):346-50.

3. Thylstrup A, Bruun C, Holmen L. In vivo caries modelsmechanisms for caries initiation and arrestment. Adv Dent Res. 1994 Jul;8(2):144-57.

4. Ferreira MAF, Mendes NS. Factors associated with active white enamel lesions. Int J Paed Dent. 2005 Sep;15(5):327-34.

5. Brandão IMG, Arcieri RM, Sundefeld MLM, Moimaz SAS. Cárie precoce: influência de variáveis sócio-comportamentais e do locus de controle da saúde em um grupo de crianças de Araraquara, São Paulo, Brasil. Cad Saúde Pública. 2006 Jun;22(6):1247-56.

6. Ribeiro AG, Oliveira AF, Rosenblatt A. Cárie precoce na infância: prevalência e fatores de risco em pré-escolares, aos 48 meses, na cidade de João Pessoa, Paraíba, Brasil. Cad Saúde Pública. 2005 Nov-Dez;21(6):1695-700.

7. Bönecker MJS, Marcenes W, Sheiham A, Guedes-Pinto AC, Walter LRF. Redução da prevalência e severidade de cárie dentária and individual educational activities to see practical demonstrations of how to perform the children's oral hygiene.

\section{Conclusions}

Considering the subjects' ages, a high prevalence of tooth enamel white spots was found in this research, mainly associated with age group, duration of bedtime milk feeding habit, age of initial practice of oral hygiene and presence of caries lesions with cavitation. Although the water fluoride level did not represent a statistically significant difference in relation to the presence of white spots, the children in the municipality with adequate fluoride content presented a lower prevalence.

The children examined presented a large amount of biofilm and there was no association between the quality of oral hygiene and the same study variables tested for white spots lesions.

em bebês. J Bras Odontopediatr Odontol Bebe. 2000 Jul-Ago; 3(14):334-40.

8. Associação Brasileira de Empresas de Pesquisa. Critério de Classificação Econômica Brasil, 2003. [citado 24 mar 2006]. Disponível em URL: http://www.abep.org.

9. Greene JC, Vermillion JR. The oral hygiene index: a method for classifying oral hygiene status. J Am Dent Assoc. 1960 Aug;61:172-9.

10. World Health Organization. Oral health surveys: basic methods. $4^{\text {th }}$ ed. Geneva: World Health Organization; 1997.

11. Brasil. Ministério da Saúde. Projeto SB Brasil 2003: Condições de saúde bucal da população brasileira 2002-2003: resultados principais. Ministério da Saúde. Secretaria de Atenção à Saúde. Departamento de Atenção Básica - Brasília: Ministério da Saúde; 2004. 68 p.

12. Barros SG, Alves AC, Pugliese LS, Reis SRA. Contribuição ao estudo da cárie dentária em crianças de 0-30 meses. Pesqui Odontol Bras. 2001;15(3):215-22.

13. Cariño KMG, Shinada K, Kawaguchi Y. Early childhood caries in northern Philippines. Community Dent Oral Epidemiol. 2003 Apr;31(2):81-9.

14. Couto GBL, Vasconcelos MMVB, Melo MMDC, Camelo CAC, Valença PAM. Prevalência da cárie, mancha branca e placa visível em crianças de 0 a 36 meses, assistidas pelo Programa de Saúde da Família na cidade de Camaragibe - PE. Odontol Clin Cient. 2005 Jan-Apr;4(1):19-27. 
15. Leite ICG, Ribeiro RA. Cárie dentária na dentição decídua de crianças assistidas em algumas creches públicas em Juiz de Fora, Minas Gerais, Brasil. Cad Saúde Pública. 2000 JulSep;16(3):717-22.

16. Milgrom O, Riedy CA, Weinstein P, Tanner ACR, Manibusan L, Bruss J. Dental caries and its relationship to bacterial infection, hypoplasia, diet and oral hygiene in 6- to 36-month-old children. Community Dent Oral Epidemiol. 2000 Aug;28(4):295-306.

17. Moimaz SAS, Martins RJ, Forte FDS, Saliba NA. Oral hygiene practices, parents' education level and dental caries pattern in 0- to 5-year-old children. Braz J Oral Sci. 2005 Aug;4(14):778-82.

18. Fraiz FC, Walter LRF. Study of the factors associated with dental caries in children who receive early dental care. Pesqui Odontol Bras. 2001 Jul-Sep;15(3):201-7.
19. Silva SMB, Oliveira FS, Pereira Júnior ES, Machado MAAM. Cárie precoce na infância: relato de caso clínico. J Bras Odontopediatr Odontol Bebe. 2001;4(22):490-6.

20. Santos APP, Soviero VM. Caries prevalence and risk factors among children aged 0 to 36 months. Pesqui Odontol Bras. 2002 Jul-Sep;16(3):203-8.

21. Cury JA, Tenuta LMA, Ribeiro CCC, Paes Leme AF. The importance of fluoride dentifrices to the current dental caries prevalence in Brazil. Braz Dent J. 2004;15(3):167-74.

22. Santos APP, Séllos MC, Ramos MEB, Soviero VM. Oral hygiene frequency and presence of visible biofilm in the primary dentition. Braz Oral Res. 2007 Jan-Mar;21(1):64-9.

23. Feitosa S, Colares V. Prevalência de cárie dentária em pré-escolares da rede pública de Recife, Pernambuco, Brasil, aos quatro anos de idade. Cad Saúde Pública. 2004 Mar-Apr;20(2):604-9. 